\title{
Study of the Connection between Personnel Training of Normal Geography Specialty and the Objective of Geographical Course in Senior High School
}

\author{
Jun Hong \\ Dean's office of Southwest Petroleum University, Chengdu, China 610500 \\ 64989598@qq.com
}

Keywords: Personnel training; Objective; Geography; High school; Connection

\begin{abstract}
This paper profoundly investigates the connection between the personnel training requirements of normal Geography Specialty in universities and the objective of geographical course in senior high school through collection of geography textbooks of senior high school and Personnel Training Plan of geography normal specialty in combination with interviews. The result shows that cultivation objectives and requirements of normal geography specialty can be summarized as physical and mental health, theoretical knowledge, as well as skill and method. These requirements have much in common with the three teaching objectives of geographical course in senior high school. Universities strengthen the connection through completing curriculum design and improving education practice in the course of personnel training, the measures make effects to some extent but the connection of "teaching process" and "emotion, attitude and value" between college and senior high school is not satisfactory. This paper suggests geography normal specialty of institution of higher learning to complete their personnel training plan and establish optimization mechanism of teaching process promote the guide of emotion, attitude and value of normal students.
\end{abstract}

\section{Introduction}

The connection between higher education and basic education plays an important part in promoting national education quality. The geographical course is a major course for students of senior high school to learn geography knowledge and have outlook on sustainable development, which connects nine-year compulsory, crosses "human and society" and "science"[1]. The geography specialty of normal university shoulders the task of cultivating future geography teacher of senior high school and has profound influence on geographical education of senior high school.

Since the geography teaching reform of Chinese colleges with certain lag and limitation is organized by their own compared to geography teaching reform of senior high school, it will lead greater disjointed occasions between colleges and the objective of geography course senior high school [2]. Therefore, this paper profoundly analyzes the connection condition of teacher-training geography specialty in university and the goal of geographical course of senior high school in combination with the objective of the new geographical course of senior high school, taking the geography specialty of three representative normal universities of Sichuan Province (Sichuan Normal University, China West Normal University and Mianyang Normal University) for examples, to provide theoretical basis for the geographical educational reform of universities.

\section{Methods}

Document and Literature. Related teaching materials about geographical normal education in universities and geographical course of senior high school were collected to establish theoretical basis of the study through induction and analysis. Literature includes Geography textbooks of Sichuan Province, the Personnel Training Plan of geographical normal specialty of the referring three universities, the New Curriculum Criteria of senior high school and related academic papers about the teaching connection between high school and universities. 
Interview. Eight geography teachers of senior high school, six geography teachers of universities and ten graduates of geography specialty in normal university were interviewed to profoundly learn about the present teaching requirements of geographical course of high school and educational situation of Geography Normal Specialty in universities, and to find prominent problems as well as the solutions of the their connection.

\section{Results and Analysis}

An Overview of Geography Curriculum Objectives of Senior High School. The overall objectives of Geography Curriculum of senior high school is to "make students to learn about the preliminary knowledge and principle of Geography; make students to gain basic geography skills, develop geographical thinking ability and have preliminary knowledge about basic methods and technical means for studying and investigate geographical problems; enhance their patriotic sentiment and help establishing their scientific outlook of population, resource and environment and outlook on sustainable development"[3]. It is a macro objective which can be realized through three micro objectives including "knowledge and skills", "process and methods" and "emotion, attitude and value".

In order to achieve the three Geography Curriculum objectives of senior high school, the New Curriculum Criteria adopts the mode of combination with compulsory course and elective course and establish three compulsory module "Geography 1", "Geography 2" and "Geography 3" respectively referring to the teaching content of physical geography, human geography and regional geography. The three modules runs through the main line of sustainable development through mutual independence and connection.

Cultivation Objectives and Requirements of Geographical Professional Personnel of Universities. The personnel cultivation goal of the three universities can be concluded educational personnel, scientific personnel, management personnel and applied personnel of geography science from their respective Personnel Training Plan. Mianyang Normal University make cultivating personnel who pursue further study as one of its training objectivity. The three universities make respective requirements of personnel training on the basis of the referring objectives, but the content is similar with each other, which are summarized in the following three aspects:

Physical and Mental Health. It requires students have healthy body with perfect personality, characteristic and mental health and good outlook on morality, world, value and life, equipped with professional belief and quality of imparting knowledge and educating people. Good aesthetic quality was also proposed by Mianyang Normal University.

Theoretical Knowledge. It requires students acknowledge basic theory, knowledge and research methods of modern Geography and learn about pedagogy and psychology.

Skills and Methods. It requires students acknowledge the remote sensing, GIS, map, field observation and laboratory simulation and analysis; master documentation retrieval and data query; master geographical teaching method and have good teaching ability; good command of computer and a foreign language.

Shen [4] summarized the personnel training requirements of Geography normal specialty of the other 6 universities including Beijing Normal University in the following 7 aspects: (1) world outlook and moral ethics, (2) principles and methods of Education, (3) professional knowledge, (4) corresponding knowledge, (5) professional skills, (6) basic skills (language and computer), (7) physical and mental health. Among them, the first 6 parts can be induced to three dimensions as emotional attitude, knowledge structure and ability structure, which are similar with the results of this study.

The Overview of the Connection Condition between University and High School. As shown in Fig. 1, there are similarities between personnel training requirements of Geography normal specialty and three course objectivity of new curriculum criteria of Geography of senior high school. But, most of the requirements of universities are result requirements, lacking of "process" requirements. Universities give teachers more teaching initiatives but less requirements of teaching 
process and methods. On the contrary, the new curriculum criteria of Geography in senior high school proposes clear guidance on teaching process through the objective of "process and methods".

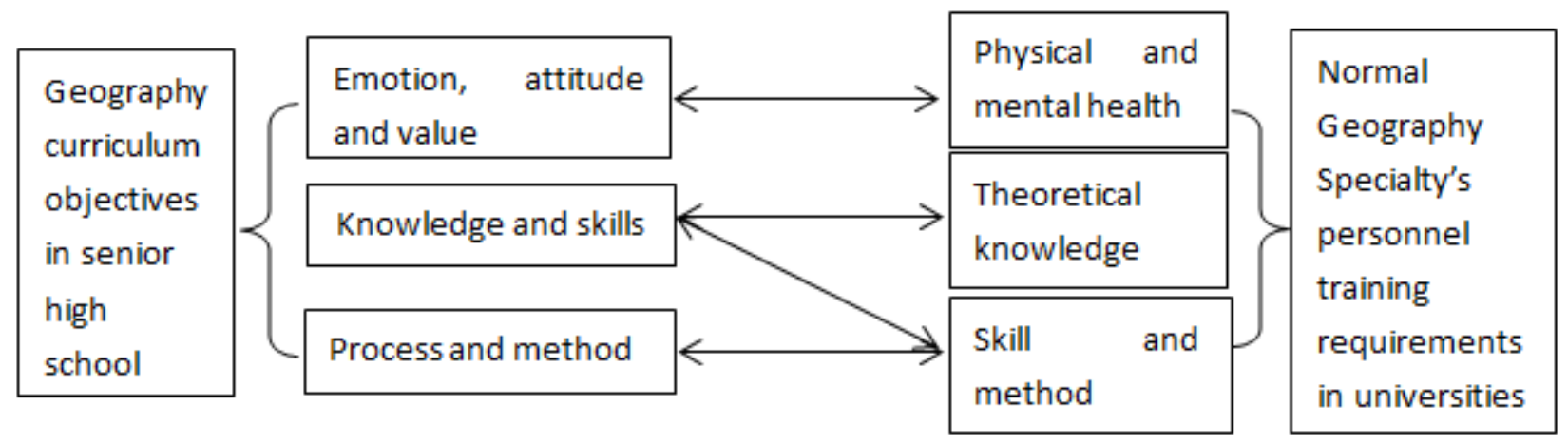

Figure. 1. The connection diagram of the geography training requirements in universities and the geography curriculum objectives in senior high school

The teaching process of teacher in universities has a strong demonstration on their students from the interview of the normal students. therefore, it is of great importance to create a lively class. However, the teaching process of different courses have great differences. College teachers prefer imparting knowledge and skills, ignoring the guidance of "emotion, attitude and value" in the professional basic courses [5]. Teachers tend to follow traditional teaching and exam-oriented assessment, attaching little importance on "process and method" of teaching in the course of teaching and assessment. Therefore, there is large disjoint in teaching process of college Geography and the objective of geographical course in senior high school, which make it hard for students experiencing the "three objectives" of geographical course in senior high school.

Major Connection Measures. Universities strengthen the connection with objectives of geography course of senior high school through completing curriculum design and improving education practice in the course of personnel training, which can be mainly concluded in the following aspects:

Professional Courses. These courses serve for imparting of professional knowledge, including physical geography, human geography and regional geography, etc [6].

Educational Courses. These courses improve normal students' physical and mental health standard and promote the establishment of their professional ethics. They also help the students acknowledge educational theory and method and learn about the teaching methods of teaching materials of high school, including Education, Psychology, Physical Education, the research of geography course and teaching materials of high school, black board-writing and mandarin, etc.

Professional Practice. This part includes the course practice of physical geography, human geography and regional geography and field practice, which contribute to the training of normal students' skills and methods.

Educational Practice. This part includes practice teaching and teaching probation that provide teaching experience for normal students and promote their acknowledgment of teaching skills and methods of geography of high school.

The referring measures enhance normal students' knowledge of curriculum objective of geography course in senior high school to some extent, on the other hand, they are likely to lead to misunderstand of teachers of other professional courses [7]. Teachers tend to think their task is to impart knowledge to students in class and "emotion, attitude and value" should be taught by teacher of Education and Psychology. They also think "process and methods" should shouldered by professional experiment and fieldwork or the course of Teaching Materials and Methods of Geography of High School. Besides, college teachers usually have the sense of "preferring scientific research to teaching", which misleads the students' teaching attitude [8]. Only when the errors are corrected, can the teaching process of geography normal specialty of universities be improved effectively. 
The geography normal specialty of universities should change education concept, complete training plan and help teachers establish correct modern views of education, curriculum, teaching, knowledge, student and evaluation and make students play the dominant role in learning to help them establish correct view and develop their comprehensive ability [9]. Universities should make use of the teaching process, focus on the teacher's demonstration effect on students, and add procedural assessment for teaching. It also needs improve the guidance of student's emotion, attitude and value and provide good study experience for normal students, teaching them not only knowledge but the methods [10]. The university should make corresponding measures to guide those teachers who prefer scientific research to teaching apply their research into teaching to enrich teaching content and arouse their interests. Training and helping measures for teachers in university should also be provided who pay less attention on teaching and do bad in teaching to arouse their teaching inspiration and encourage them to create new teaching mode, thus improving their teaching standard.

\section{Summary}

The normal geography specialty of universities fulfill the connection with the objectives of geographical course of senior high school mainly through perfecting the curriculum design and enhancing teaching practice. Its personnel training requirements have commons with the objectives of geographical course in senior high school, but geography normal education of universities pay little importance on the teaching process and the guidance of students' emotion, attitude and value.

\section{References}

[1] J.B. Fu and S.L. Chen: Journal of Gansu Union University (Natural Science Edition), Vol. 25 (2011) No.2, p.101.(In Chinese)

[2] P. Sun: Research on the geography curriculum content link between College and high school. (MS, Xinyang Normal University, China 2014), p.6.

[3] C. Chen and J. Fan: Interpretation of geography curriculum standard in general senior high school. (Jiangsu Education Press, China 2004) p. 85.

[4] H. Shen. Studies of cultivation objective of Geography teacher of senior high school in the background of new curriculum standard reform. (MS., Zhejiang Normal University, China 2007), p.18.

[5] Y. Zhang: Theory and Practice of Contemporary Education, Vol. 4 (2012) No.5, p.111.(In Chinese)

[6] H. Wang: Higher Education of Sciences, Vol. 10 (2012) No.5, p.141.(In Chinese)

[7] Z.Xu: Heilongjiang Researches on Higher Education, Vol. 15 (2010) No.5, p.159.(In Chinese)

[8] J.X. Zhang, S.T. Yang and D.Q. Huang: Journal of Anhui Agricultural Sciences, Vol. 38 (2010) No.30, p.173.(In Chinese)

[9] J.C. Li and S.Q.Luo: Research in Educational Development, Vol. 25 (2011) No.21, p.47.(In Chinese)

[10] Y.H. Fu: Modern Primary and Secondary Education, Vol. 12 (2014) No.2, p.106.(In Chinese) 